\title{
PENGEMBANGAN TOPOLOGI INVERTER MULTILEVEL TIGA TINGKAT SATU FASA TIPE DIODE CLAMPED DENGAN MEREDUKSI KOMPONEN SAKLAR DAYA
}

\author{
Hendi Matalata* dan Muh.Imran Hamid \\ Jurusan Teknik Elektro, Fakultas Teknik, Universitas Andalas \\ *Corresponding author, e-mail : dermahadihendi@yahoo.co.id
}

\begin{abstract}
Abstrak - Inverter multilevel adalah konverter yang mengubah sumber listrik DC menjadi sumber listrik AC dengan keluaran tegangan lebih dari dua tingkat. Topologi konvensional inverter multilevel untuk tiga tingkat yang berkembang saat ini umumnya menggunakan empat komponen saklar daya. Dalam paper ini diketengahkan sebuah topologi inverter multilevel tiga tingkat dengan mereduksi komponen saklar daya menjadi dua buah dan dinamakan sebagai inverter multilevel tipe diode clamped tiga tingkat satu phasa. Simulasi dengan MATLAB yang telah dilakukan menunjukkan berbagai kelebihan topologi ini dibandingakan dengan topologi yang ada sebelumnya. Selanjutnya topologi direalisasikan untuk dapat mengetahui unjuk kerjanya secara ril. Pengujian yang dilakukan menunjukkan prospek topologi ini untuk dapat diaplikasikan pada berbagai keperluan.
\end{abstract}

\section{Kata kunci: Inverter Multilevel, Dioda Clamped, Komponen Saklar Daya, Reduksi}

\begin{abstract}
Multilevel inverter is a converter which converts the DC power source into an AC power source with a voltage output of more than two levels. Conventional multilevel inverter topology for the three levels developed at this time generally uses four components of the power switch. In this paper presented a threelevel multilevel inverter topology by reducing the power switch components into two pieces and named as the type of diode clamped multilevel inverter three level one phase. Simulation with MATLAB have shown the many advantages of this topology is compared with the existing topology. Furthermore topology realized in order to determine their performance in real terms. Tests have shown the prospects of this topology to be applied to a variety of purposes.
\end{abstract}

Keywords: Multilevel Inverter, Diodes clamped, Components Power Switch, Reduction

Copyright (C) 2016 JNTE. All rights reserved

\section{PENDAhULUAN}

Perkembang elektronika daya telah memungkinkan untuk dihasilkannya system pembangkitan, pemprosesan dan penggunaan energi listrik secara efesien dan ekonomis. Dengan kelebihan ini, peralatan elektronika daya semakin banyak diterapkan dalam berbagai sektor industri seperti: pemanfaatan sumber daya DC, uninterruptible power supplies, transmisi daya tegangan searah (HVDC), sistem penggerak frequensi variabel, air conditioner dan aplikasi lainnya.

Elektronika daya didefinisikan sebagai aplikasi elektronika yang menitikberatkan pada pengaturan peralatan listrik dengan cara melakukan perubahan parameter-parameter listrik (arus, tegangan, frekuensi dan daya listrik). Aplikasi elektronika yang dimaksud adalah rangkaian yang menggunakan peralatan elektronika yang difungsikan untuk melakukan pengaturan dengan cara pengubahan tipe sumber (konverter) dari AC-DC, AC-AC, DCDC dan DC-AC.

Salah satu jenis konverter daya yang banyak digunakan adalah inverter. Selanjutnya, dengan berbagai tuntutan kebutuhan, inverter berkembang menjadi berbagi jenis diman salah satu variannya adalah inverter multilevel. Inverter multilevel adalah konverter dc-ac dimana bentuk keluaran tegangan lebih dari dua tingkat (tiga tingkat, lima tingkat, tujuh tingkat dan seterusnya). Banyaknya tingkat keluaran sebuah inverter multilevel diatur dengan rangkaian kendali (switch) dan rangkaian switching, semakin banyak tingkat tegangan maka keluaran akan mendekati gelombang sinusoidal, dan. kualitas daya yang dihasilkan lebih baik. 
Inverter multilevel yang berkembang saat ini dapat dikenali berdasarkan arsitekturnya (topologi), seperti topologi Diode Clamped, Flying Capacitor dan H-Bridge. Topologi inverter multilevel yang paling sederhana saat ini adalah inverter tiga tingkat, dimana tingkat tegangan yang dihasilkan yaitu tegangan positif, nol dan tegangan negatif yang dihasilkan dengan menggunakan empat saklar daya. Namun demikian, sejumlah penelitian terus dilakuklan untuk pengembangan dan untuk menghasilkan bentuk tegangan tiga tingkat dengan mereduksi kimponen saklar daya yang digunakan.

Dalam paper ini diketengahkan sebuah topologi inverter multilevel tiga tingkat yang lebih sederhana yang dikembangkan dari reduksi empat saklar daya menjadi dua namun dihasilkan kualitas tegangan yang sama [1].

\section{KELUARAN INVERTER MULTILEVEL}

Bentuk dasar keluaran inverter multilevel tiga tingkat tegangan adalah diperoleh dengan memodifikasi gelombang persegi untuk menyerupai gelombang sinus, dengan cara mengubah level tegangan secara berkelanjutan dari nol, kemudian naik atau turun dengan peningkatan atau penurunan tingkat tegangan yang tertentu, [2].

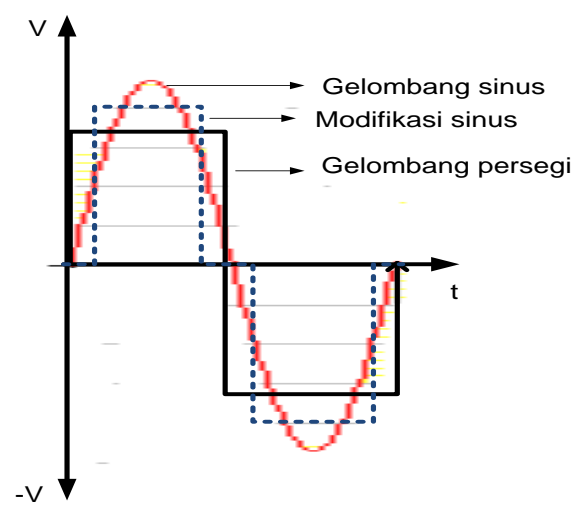

Gambar 1. Gelombang Keluaran Tiga Tingkat

Seperti dijelaskan pada gambar diatas gelombang sinus ditirukan dengan cara memodifikasi gelombang persegi sedemikian rupa sehingga terbentuk gelombang persegi tetapi memiliki delay tertentu pada setiap setengah periodenya. Dengan deret fourier, gelombang persegi tersebut dapat dinyatakan sebagai penjumlahan komponen-komponen harmonik dan dinyatakan dalam persamaan berikut [3]:

$\mathrm{V}_{0}(\omega \mathrm{t})=\mathrm{V}_{0}+\sum_{\mathrm{n}=1}^{\infty}\left(\mathrm{a}_{\mathrm{n}} \sin \mathrm{n} \omega \mathrm{t}\right)+$

$\sum_{n=1}^{\infty}\left(b_{n} \cos n \omega t\right)$

$V_{0}=\frac{1}{2 \pi} \int_{0}^{2 \pi} V_{0}(\omega t) d \omega t$

$a_{n}=\frac{1}{\pi} \int_{0}^{2 \pi} V_{0}(\omega t) \sin n \omega t d \omega t$

$b_{n}=\frac{1}{\pi} \int_{0}^{2 \pi} V_{0}(\omega t) \cos n \omega t d \omega t$

Persamaan deret fourier (1) dapat ditulis dalam bentuk:

$V_{0}(\omega t)=\frac{A_{0}}{2}+\sum_{n=1}^{\infty} A_{n} \cos \left(n \omega t+\theta_{n}\right)$

$A_{n}=\sqrt{a_{n}^{2}+b_{n}^{2}}$

$\theta_{\mathrm{n}}=\tan ^{-1}\left(\frac{-\mathrm{b}_{\mathrm{n}}}{\mathrm{a}_{\mathrm{n}}}\right)$

Selanjutnya, tegangan dan arus efektif jika dinyatakan dalam bentuk komponen harmonik dituliskan dengan persamaan berikut:

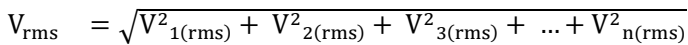

$\mathrm{I}_{\mathrm{rms}}=\sqrt{\mathrm{I}^{2} 1(\mathrm{rms})+\mathrm{I}^{2} 2(\mathrm{rms})+\mathrm{I}^{2}{ }_{3(\mathrm{rms})}+\ldots+\mathrm{I}^{2} \mathrm{n}(\mathrm{rms})}$

Dimana:

$\mathrm{V}_{1 \text { (rms) }}=$ tegangan efektif harmonik dasar

$\mathrm{V}_{\mathrm{n}(\mathrm{rms})}=$ tegangan efektif harmonik ke $\mathrm{n}$

$\mathrm{I}_{1 \text { (rms) }}=$ arus harmonik dasar

$\mathrm{I}_{\mathrm{n}(\mathrm{rms})}=$ arus harmonik ke $\mathrm{n}$

Tingkat distorsi gelombang yang dihasilkan diukur dengan besaran THD, dinyatakan dalam persen (\%) dan dirumuskan sebagai berikut:

$$
\begin{aligned}
\mathrm{THD} & =\frac{\sqrt{\mathrm{V}^{2} 2(\mathrm{rms})+\mathrm{V}^{2}{ }_{3(\mathrm{rms})}+\mathrm{V}^{2}{ }_{4(\mathrm{rms})}+\cdots+\mathrm{V}^{2} \mathrm{n}(\mathrm{rms})}}{\mathrm{V}_{1(\mathrm{rms})}} \\
& =\frac{\sqrt{\mathrm{V}^{2} \mathrm{rms}^{-} \mathrm{V}^{2} 1(\mathrm{rms})}}{\mathrm{V}_{1(\mathrm{rms})}}
\end{aligned}
$$


3. TOPOLOGI INVERTER MULTILEVEL TIGA TINGKAT TIPE DIODE CLAMPED

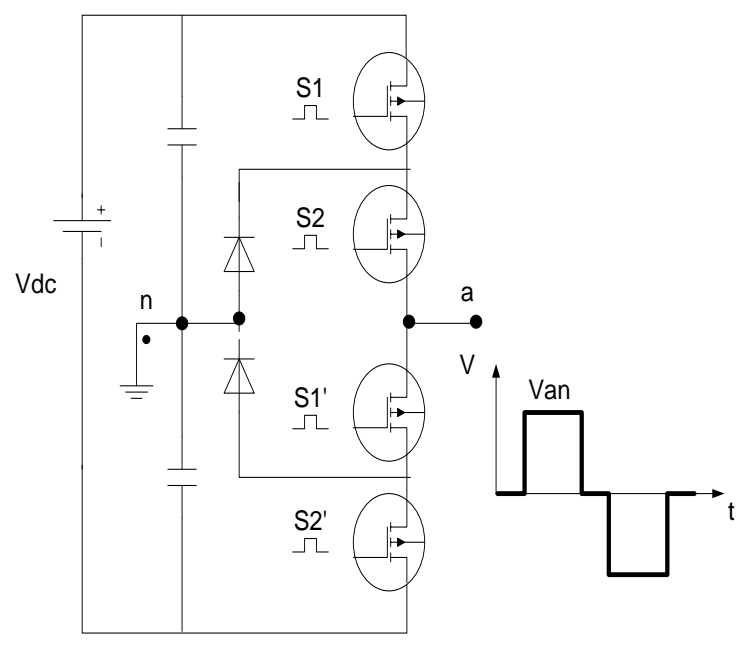

Gambar 2. Topologi Inverter Multilevel Tiga Tingkat Tipe Diode Clamped Menggunakan 4 Komponen Saklar Daya[4]

Pada Gambar 2, untuk menghasilkan keluaran tiga tingkat (Van), diperlukan 4 buah switch (S1,S2,S1' dan S2') komponen elektronika daya (komponen saklar daya), unit switch bekerja secara bergantian (ON/OFF) untuk mencacah input DC-nya. Saat S1, S2 pada kondisi ON dan S1', S2' pada kondisi OFF maka keluaran berada pada $1 / 2 \mathrm{Vdc}$ siklus positif, saat S2, S2' pada kondisi ON dan S1, S1' pada kondisi OFF maka keluaran berada pada $0 \mathrm{Vdc}$ demikian pula saat $\mathrm{S} 1, \mathrm{~S} 1$ ' pada kondisi $\mathrm{ON}$ dan S2, S2' pada kondisi OFF. Sedangkan pada saat S1', S2' pada kondisi ON dan S1, S2 pada kondisi OFF maka keluaran berada pada $-1 / 2$ Vdc siklus negatif. Kondisi unit status switch dijelaskan pada Tabel 1.

Tabel 1. Status Saklar Daya

\begin{tabular}{lcc}
\multicolumn{1}{c}{ Switch } & Kondisi & Keluaran \\
\hline $\mathrm{S} 1=\mathrm{ON}, \mathrm{S} 2=\mathrm{ON}$ & $\mathrm{S}=+\mathrm{ve}$ & $\mathrm{Vdc} / 2$ \\
$\mathrm{~S} 1^{\prime}=\mathrm{OFF}, \mathrm{S} 2^{\prime}=\mathrm{OFF}$ & & \\
\hline $\begin{array}{l}\mathrm{S} 1=\mathrm{OFF}, \mathrm{S} 2=\mathrm{ON} \\
\text { S1'=ON, S2'=OFF }\end{array}$ & 0 & 0 \\
\hline $\begin{array}{l}\text { S1=OFF, S2=OFF } \\
\text { S1'=ON, S2'=ON }\end{array}$ & $\mathrm{S}=-\mathrm{ve}$ & $-\mathrm{Vdc} / 2$ \\
\hline
\end{tabular}

Kondisi sinyal switch dari keterangan Tabel 1 dilihat pada Gambar 3 :

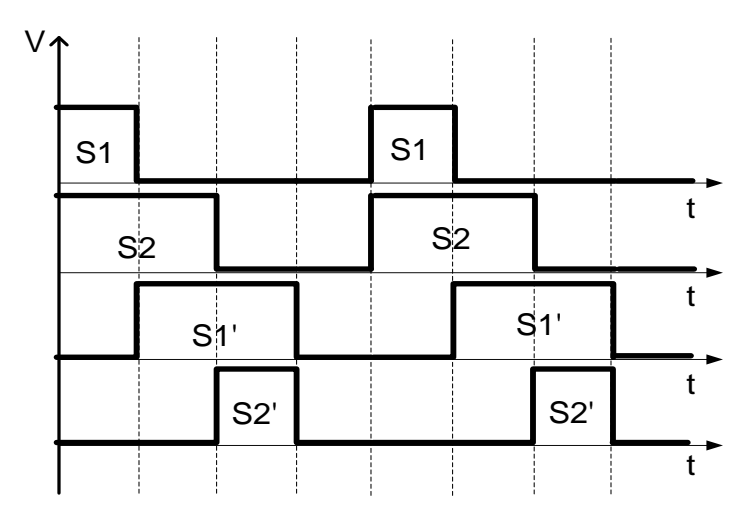

Gambar 3. Kondisi Sinyal Switch Inverter Multilevel Tiga Tingkat[5]

Dari pemaparan inverter multilevel tiga tingkat diatas, terlihat bahwa untuk menghasilkan tegangan tiga tingkat dilakukan dengan operasi 4 buah saklar daya dan menggunakan rangkaian yang dilengkapi dengan dioda yang disebut diode clamped. Sub bab berikutnya akan mengetengahkan disain topologi multilevel tiga tingkat yang diperoleh hanya menggunakan komponen saklar daya sebanyak 2 buah (reduksi komponen saklar daya).

\section{TOPOLOGI INVERTER MULTILEVEL TIGA TINGKAT TIPE DIODE CLAMPED MENGGUNAKAN 2 KOMPONEN SAKLAR DAYA}

Gambar 4 memperlihatkan topologi inverter multilevel tiga tingkat yang menggunakan 2 buah saklar daya.

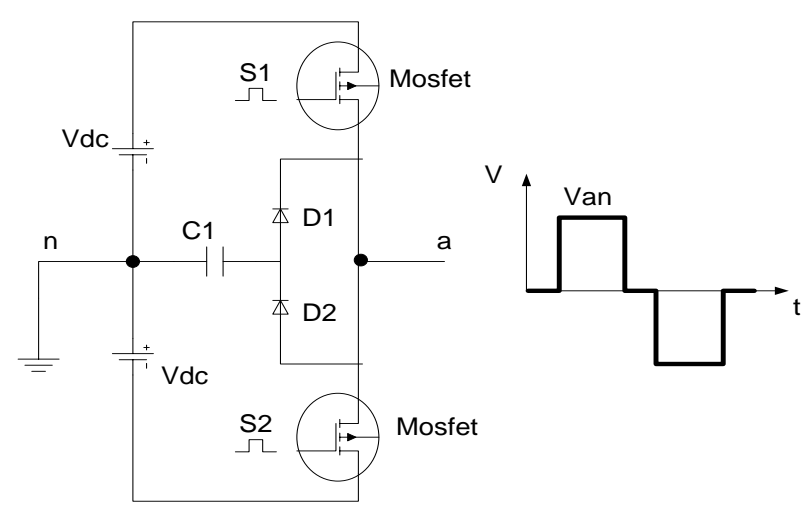

Gambar 4. Topologi Inverter Multilevel Tiga Tingkat Tipe Diode Clamped Menggunakan 2 Komponen Saklar Daya 
Dari Gambar 4, S1 dan S2 adalah unit switch atau gate driver untuk komponen saklar daya (MOSFET), sedangkan D1 dan D2 adalah dioda yang digunakan untuk membatasi peralihan kondisi ON/OFF unit komponen saklar daya terhadap sumber Vdc-nya. Status dari masingmasing komponen daya dituangkan kedalam Tabel 2 berikut:

Table 2. Status Saklar Daya

\begin{tabular}{cccc}
\hline Switch & Keadaan 1 & Keadaan 2 & Keluaran \\
\hline S1 & ON & OFF & Vdc \\
\hline $\begin{array}{c}\text { S1 } \\
\text { dan } \\
\text { S2 }\end{array}$ & OFF & OFF & 0 \\
\hline S2 & OFF & ON & -Vdc \\
\hline
\end{tabular}

Pada saat S1 dalam keadaan ON, S2 pada kondisi OFF keluaran inverter pada periode positif tegangan sumber $(+\mathrm{Vdc})$. Pada saat selang waktu tertentu $\left(\mathrm{t}_{0}\right)$ yaitu ketika $\mathrm{S} 1$ dan $\mathrm{S} 2$ dalam keadaan OFF, keluaran inverter pada periode nol dari tegangan sumber, selanjutnya pada saat S1 dalam keadaan OFF, S2 pada kondisi ON keluaran inverter pada periode negatif tegangan sumber $(-\mathrm{Vdc})$ dan pada saat selang waktu tertentu $\left(\mathrm{t}_{0}\right)$ yaitu $\mathrm{S} 1$ dan $\mathrm{S} 2$ dalam keadaan OFF keluaran inverter pada periode nol. Pembentukan sinyal pulsa S1 dan S2 seperti penjelasan gambar dibawah.

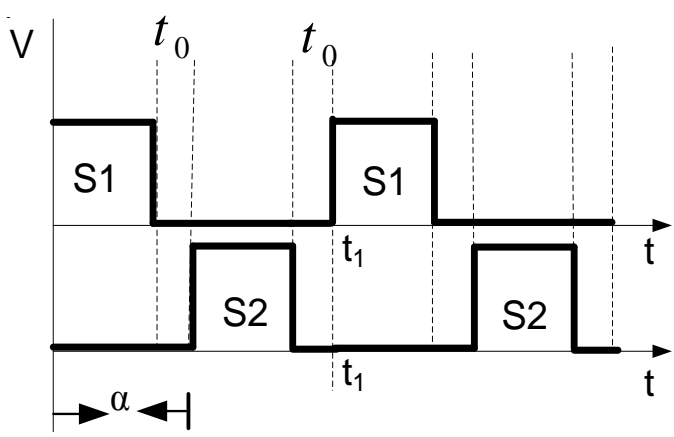

Gambar 5. Model Sinyal Switch (Pulsa) Inverter Multilevel Tiga Tingkat

Berdasarkan gambar model diatas untuk pembentukan sinyal switch PWM diambil ketentuan sebagai berikut[6] :

1. Duty cycle $<0,5$

2. $\mathrm{t}_{0}<\frac{\mathrm{t}_{1}}{2}$

3. $\alpha<180^{\circ}$
5. PERBANDINGAN

TOPOLOGI

INVERTER MULTILEVEL TIGA

TINGKAT MENGGUNAKAN 4

KOMPONEN SAKLAR DAYA DENGAN

MENGGUNAKAN 2 KOMPONEN

SAKLAR DAYA

Dari pemaparan topologi inverter multilevel untuk tiga tingkat diatas, pada bagian ini besarnya harmonik tegangan dihitung melalui simulasi MATLAB. Pada simulasi, besar harmonik tegangan diukur pada frekuensi fundamental $500 \mathrm{~Hz}$.

Simulasi yang dilakukan ditujukan untuk memperlihatkan bahwa untuk level harmonik tegangan output yang sama yang dihasilkan dari topologi inverter multilevel 4 komponen saklar daya, level harmonik yang sama dapat diperoleh dengan menggunakan topologi yang hanya menggunakan 2 komponen saklar daya.

\subsection{Simulasi Inverter Multilevel Tipe Diode} Clamped Menggunakan 4 Komponen Saklar Daya

Gambar 6 memperlihatkan model simulasi matlab inverter multilevel menggunakan 4 komponen saklar daya yang terdiri dari empat buah MOSFET, sedangkan blok kontroler merupakan rangkaian pembentukan sinyal pulsa sebagai gate driver MOSFET.
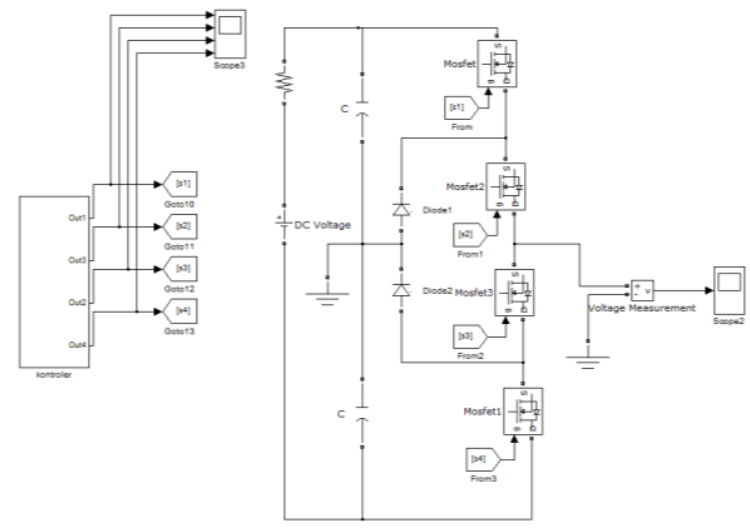

Gambar 6. Model Simulasi MATLAB Inverter Multilevel Tiga Tingkat Menggunakan 4 Komponen Saklar Daya [7]

Dari Gambar model simulasi inverter multilevel tiga tingkat diatas, sumber tegangan pada rangkaian daya diset sebesar 10 Volt, dan proses pembangkitan sinyak PWM ditampilkan 
pada blok scope3 dengan keluaran bentuk gelombang seperti Gambar 7.

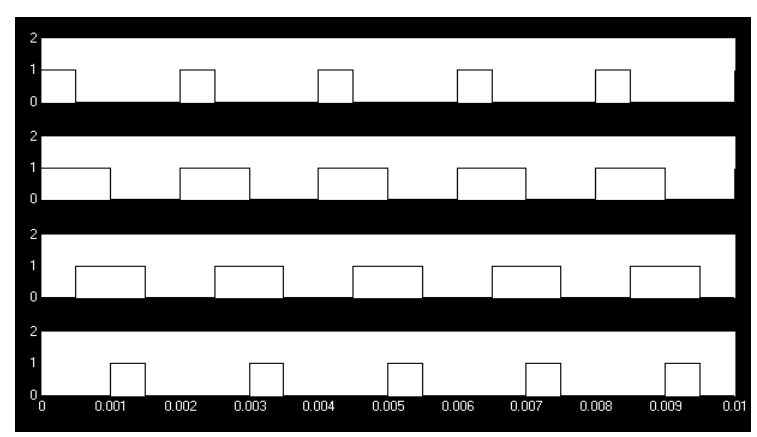

Gambar 7. Sinyal Pulsa S1, S2, S3 dan S4 (Gate Driver)

Amplitudo sinyal pulsa diset sebesar 1 Volt dengan frekuensi $500 \mathrm{~Hz}$. Sedangkan bentuk keluaran inverter multilevel tiga tingkat pada rangkaian model simulasi MATLAB ditunjukan pada pengukuran scope2, adapun hasilkan keluaran scope2 dapat dilihat pada gambar dibawah.

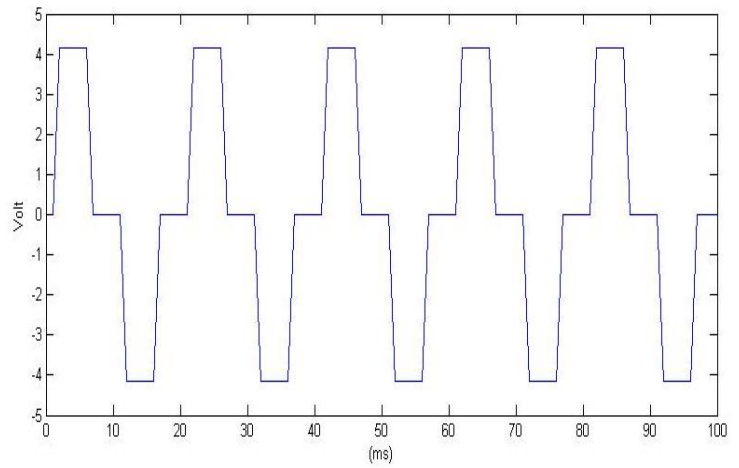

Gambar 8. Inverter Multilevel Tiga Tingkat Menggunakan 4 Komponen Saklar Daya

Bentuk keluaran dari hasil simulasi menunjukan besar amplitudo tegangan 4,2 Volt pada setengah periode sesuai dengan jatuh tegangan pada kopling kapasitor atas dan $-4,2$ volt pada setengah periode berikutnya sesuai dengan jatuh tegangan pada kopling kapasitor bawah. Sedangkan untuk mendapatkan besar harmonik tegangan yang dihasilkan pada rangkaian model simulasi matlab, dalam Analisis Fast Fourier Transfrom pada frekuensi fundamental $500 \mathrm{~Hz}$ ditunjukan pada gambar 9 dibawah, dimana THD diperoleh sebesar 47,28 $\%$ [8].

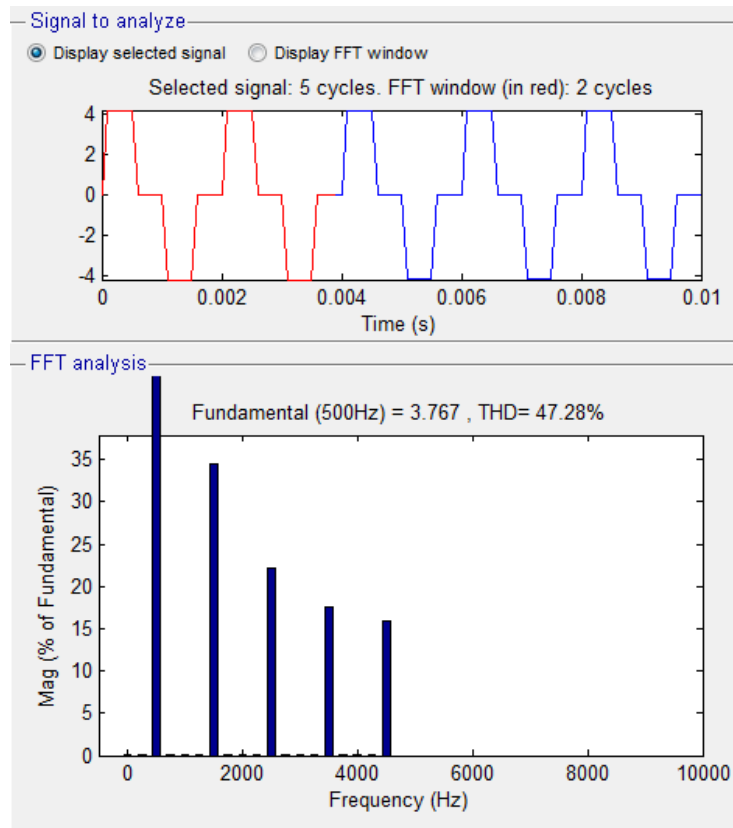

Gambar 9.Total Harmonic Distortion Analisis FFT Inverter Multilevel Tiga Tingkat Menggunakan 4 Komponen Saklar Daya

\subsection{Simulasi Inverter Multilevel Tipe Diode Clamped Menggunakan 2 Komponen Saklar Daya \\ Gambar 10 memperlihatkan model simulasi} MATLAB inverter multilevel tiga tingkat namun menggunakan dua buah komponen saklar daya (MOSFET). Dengan hanya terdiri dari dua komponen saklar daya, maka berbagai rangkaian pendukung dapat direduksi seperti rangkaian pembangkit pulsa, gate driver dan sebagainya.

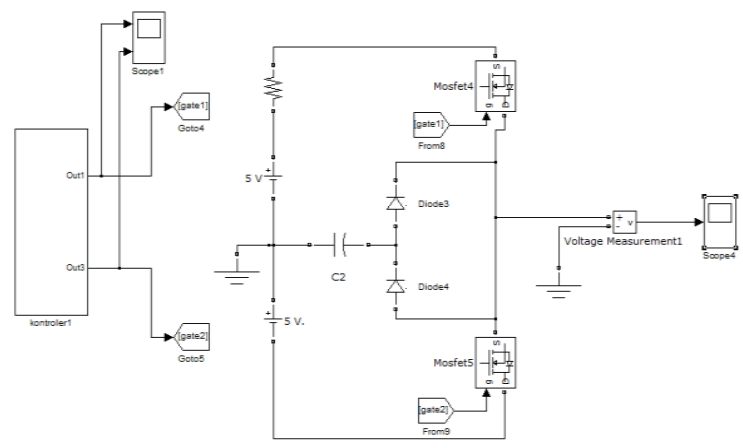

Gambar 10. Model Simulasi MATLAB Inverter Multilevel Menggunakan 2 Komponen Saklar Daya

Model simulasi inverter multilevel tiga tingkat diatas diset menggunakan dua buah 
sumber tegangan pada rangkaian daya masingmasing sebesar 5 Volt. Proses untuk menghasilkan sinyal gate komponen saklar daya diperoleh pada blok kontroler 1 dan diperlihatkan dengan blok scope1 dengan bentuk gelombang sebagaimana Gambar 11 berikut:

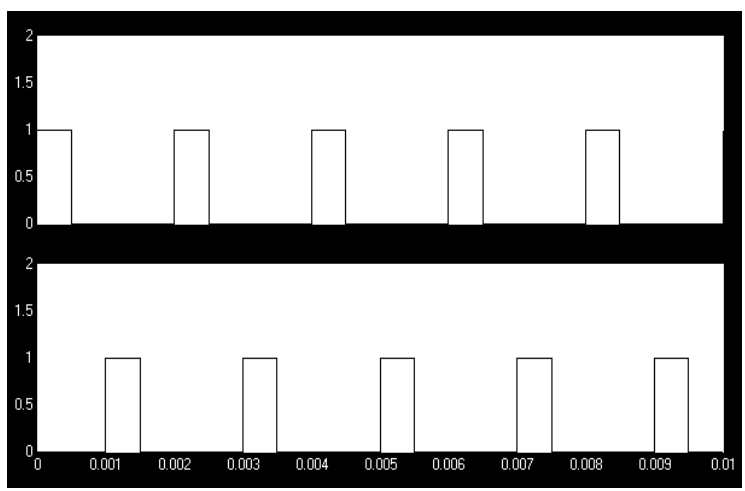

Gambar 11. Switch 1 dan Switch 2

Duty cycle Switch 1 dan Switch 2 pada gambar 11 diatas sebesar $25 \%$ dengan sudut $\alpha$ pada switch 1 sebesar $0^{0}$ sedangkan sudut $\alpha$ pada switch 2 digeser sejauh $180^{\circ}$, dimana masingmasing frekuensi sinyal switch sebesar $500 \mathrm{~Hz}$.

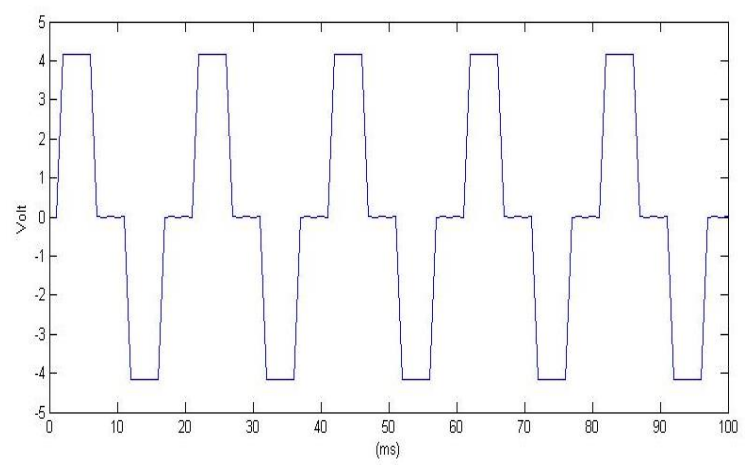

Gambar 12. Keluaran Inverter Multilevel Tiga Tingkat Menggunakan 2 Komponen Saklar Daya

Bentuk keluaran dari hasil simulasi menunjukan bentuk gelombang keluaran persegi dan delay untuk setiap setengah siklus periode gelombang sebesar 0,2 ms dengan frekuensi 500 Hz. Sedangkan untuk mendapat besar harmonik tegangan yang dihasilkan pada rangkaian model simulasi MATLAB. Analisis dalam Fast Fourier Transfrom pada frekuensi fundamental $500 \mathrm{~Hz}$ ditunjukan pada Gambar 13 dibawah, dimana THD diperoleh sebesar 47,28\%.

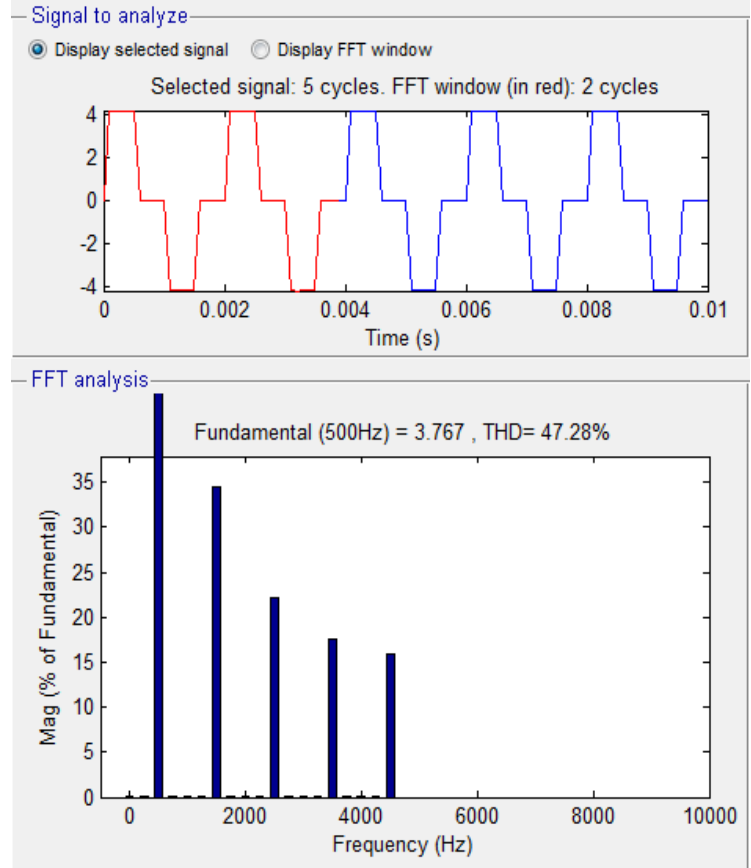

Gambar 13.Total Harmonic Distortion Analisis FFT Inverter Multilevel Menggunakan 2 Komponen Saklar Daya

Dari hasil perbandingan simulasi kedua topologi inverter multilevel seperti yang telah dilakukan, didapatkan bahwa untuk besar harmonik dan bentuk tegangan keluaran yang sama, dapat dihasilkan oleh kedua topologi tersebut. Dengan demikian topologi multilevel inverter tiga tingkat dengan 4 komponen saklar daya dapat digantikan dengan topologi yang lebih efisien yaitu toplogi dengan menggunakan 2 komponen saklar daya.

Untuk memperlihatkan unjuk kerja dan kelebihan topologi yang dirancang, dilakukan perancangan alat yaitu dengan merealisasikan perangkat keras dan pengujiannya sebagaimana akan diuraikan pada sub bab selanjutnya.

\section{REALISASI INVERTER MULTILEVEL TIGA TINGKAT TIPE DIODE CLAMPED MENGGUNAKAN 2 KOMPONEN SAKLAR DAYA}

Gambar 14 menunjukkan skema lengkap rangkaian inverter multilevel tiga tingkat yang terdiri dari rangkaian daya dan rangkaian pembangkit pulsa bagi sinyal gating komponen saklar daya. 


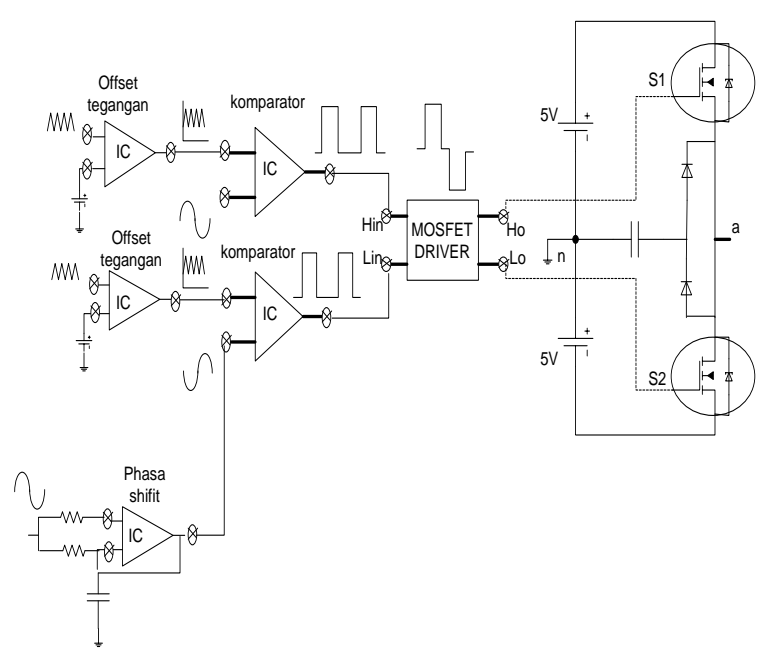

Gambar 14. Skematik lengkap Rangkaian Inverter Multilevel Tiga Tingkat Satu fasa Tipe Diode Clamped

Sementara itu, Gambar 15 menunjukkan realisasi rangkaian inverter yang dimaksud. Rangkaian daya terdiri dua buah komponen MOSFET RFP12N10L yang dipasang pada satu leg dengan masing-masing satu dioda pembentuk rangkaian inverter multilevel tiga tingkat satu fasa. Rangkaian driver dibangun melalui modulasi dua buah sinyal pada komparator IC LM 393. Output hasil komparasi ini selanjutnya diinputkan pada rangkaian driver MOSFET IR2110 dari International Rectifier (diperlihatkan pada Gambar 16)

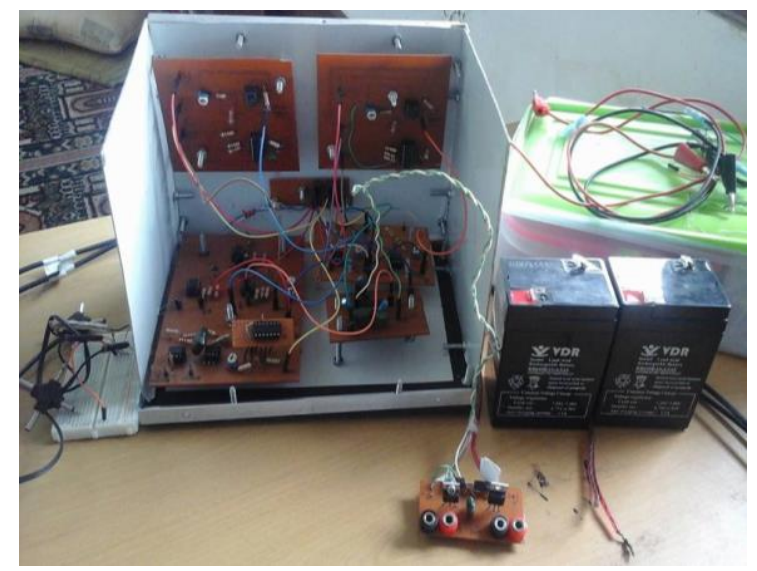

Gambar 15. Realisasi Rangkaian Inverter Multilevel dan Gate Driver

Untuk mendapatkan bentuk tingkat tegangan dari rangkaian daya Gambar 15 diatas sumber DC menggunakan dua buah baterai dengan kapasitas 5 volt / 4,5 Ah.

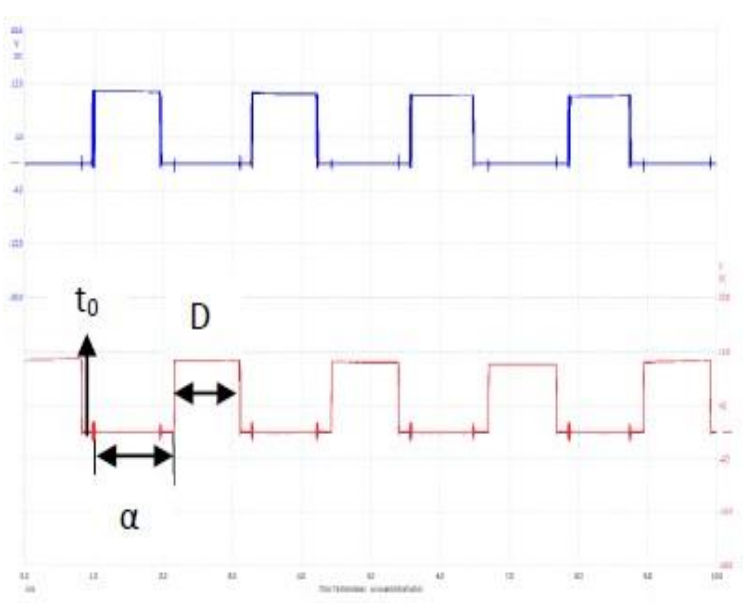

Gambar 16. Bentuk Sinyal Switch 1 dan Switch $2 \mathrm{~T}=2 \mathrm{~ms}$, picoscope 4227

Gambar 16 diatas memperlihatkan bentuk keluaran komparator LM 393 yang menjadi input untuk IC Driver IR 2110 (Gambar 17). Kedua sinyal ini mempunyai besaran sebagai berikut : $\mathrm{t}_{0}<\frac{\mathrm{t}_{1}}{2}$, dutycycle (D) $<0.5, \alpha<180^{\circ}$ dan amplitudo 10 volt, dimana besar amplitudo tersebut didapat berdasarkan tegangan kerja yang diberi pada komponen pembangkitan sinyal switch PWM.

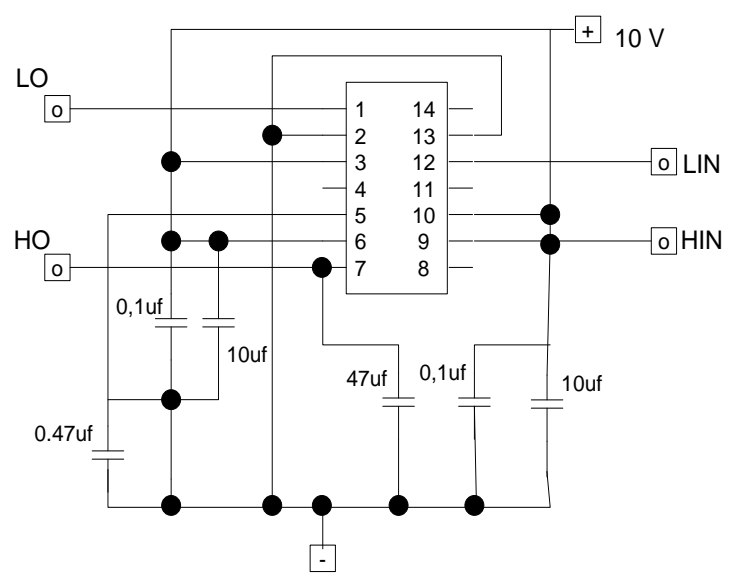

Gambar 17. Skema Rangkaian IC driver IR 2110

IC driver IR 2110 bekerja pada tegangan Vcc 10 volt -28 volt, memiliki dua input LIN dan HIN dan pin output LO dan HO. Subskrip L dan $\mathrm{H}$ menunjukkan sisi komponen switch pada suatu Leg inverter. Dengan input sinyal seperti pada Gambar 16 diatas, IC driver IR 2110 memberikan output pada kaki-kakinya seperti terlihat pada Gambar 18. 


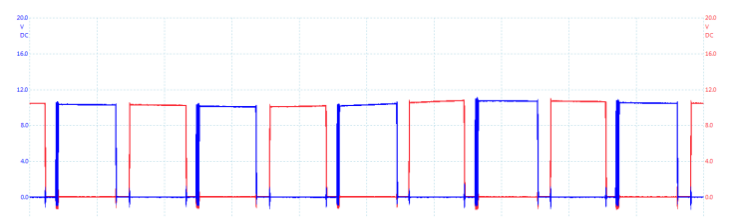

Gambar 18. Keluaran IC Gate Driver, $\mathrm{T}=2 \mathrm{~ms}$, picoscope 4227

Gambar 19 memperlihatkan hasil akhir output dari inverter multilevel yang memperlihatkan tiga tingkat tegangan yang terjadi. Tegangan ini diperoleh melalui switching komponen saklar daya dengan pola sebagaimana diuraikan sebelumnya.

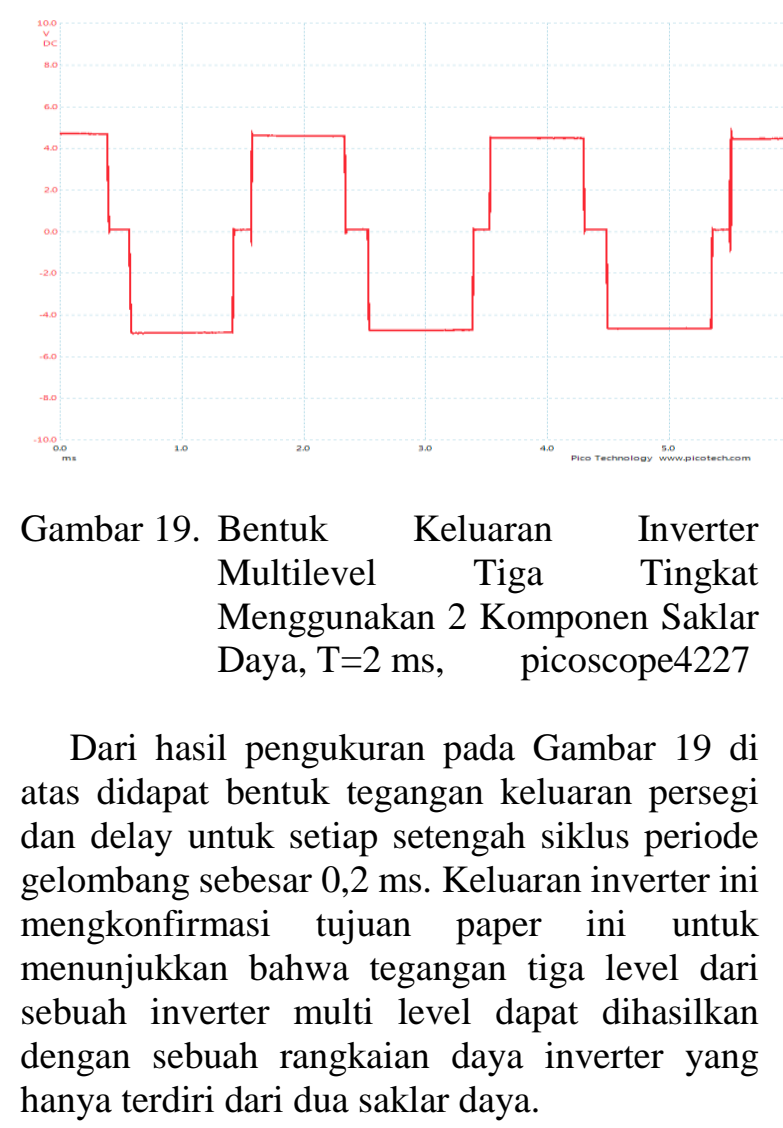

\section{KESIMPULAN}

Dalam paper ini telah dipaparkan sebuah desain topologi inverter multilevel tiga tingkat satu fasa tipe diode clamped dengan mereduksi jumlah komponen saklar daya. Realisasi uji perangkat keras telah membuktikan bahwa untuk inverter multilevel tiga tingkat keluaran, jumlah komponen saklar daya dapat direduksi dengan menggunakan dua komponen saklar daya. Implementasi dari perangkat keras yang dibuat juga dapat direalisasikan dalam berbagai aspek keperluan.

\section{DAFTAR PUSTAKA}

[1] R. A. Ahmed and H. W. Ping, "New multilevel inverter topology with reduced number of switches," Proccediing of the International Midldle East Power System Conference(MEPCON'10), Cairo, pp. 565-570, 2010.

[2] A. S. J. Bitar and I. F. Crowley, "PWM Techniques : A Pure Sine Wave Inverter," Major Qualifying Project, Worcester, 2011.

[3] M. Sukmawidjaja, "ELIMINASI HARMONIK GUNA PERBAIKAN," JETri, vol. 6, no. 1, pp. 9-32, 2006.

[4] V. Sahu and S. Kaushik, "A New FiveLevel Diode Clamp Multilevel Inverter Topology," Int. J. Creat. Res. Thoughts, vol. 1, no. 4, pp. 2-5, 2013.

[5] M. Derakhshanfar, "Analysis of different topologies of multilevel inverters," CHALMER UNIVERSITY OF TECHNOLOGY, 2010.

[6] Fitriadi, Muh. Imran Hamid, "DESAIN RANGKAIAN GATE-DRIVER UNTUK KONVERTER YANG BEKERJA DENGAN VOLTAGE MODE CONTROL," jnte, vol. 5, no. 2, pp. 1-6, 2016.

[7] E. aptono Triyuwono, "Inverter Multi Level Tipe Jembatan Satu Fasa Tiga Tingkat," TRANSMISI, vol. 13, no. 4, pp. 135-140, 2011.

[8] R. Chaturvedi, "A Single Phase Diode Clamped Multilevel Inverter and its Switching Function," J. Innov. trends Sci. Pharm. Technol., vol. 1, no. 1, pp. 2-5, 2014.

\section{Biodata Penulis}

Hendi Matalata, lahir di Perbaungan tanggal 05 mei 1980, mahasiswa Pasca Sarjana Jurusan Teknik Elektro Fakultas Teknik Universitas Andalas Padang, Dosen Luar Biasa Universitas Batanghari Jambi JurusanTeknik Listrik D3. 